NBER WORKING PAPER SERIES

\title{
R\&D SOURCING, JOINT VENTURES AND INNOVATION: \\ A MULTIPLE INDICATORS APPROACH
}

\author{
James D. Adams \\ Mircea Marcu \\ Working Paper 10474 \\ http://www.nber.org/papers/w10474
}

\author{
NATIONAL BUREAU OF ECONOMIC RESEARCH \\ 1050 Massachusetts Avenue \\ Cambridge, MA 02138
}

May 2004

This research was supported by NSF grant SBR-9502968. We have benefited from seminars given at the State University of New York at Albany, Union College, Rensselaer Polytechnic Institute, and the Boston University School of Management; and from comments by Don Siegel and Ken Simons. Eleanora Voelkel, Meg Fernando, and Richard Anderson administered the Survey of Industrial Laboratory Technologies 1996 that yielded the data that underlie the findings. We alone are responsible for the opinions expressed in this paper.The views expressed herein are those of the author(s) and not necessarily those of the National Bureau of Economic Research.

(C2004 by James D. Adams and Mircea Marcu. All rights reserved. Short sections of text, not to exceed two paragraphs, may be quoted without explicit permission provided that full credit, including (C notice, is given to the source. 
R\&D Sourcing, Joint Ventures and Innovation: A Multiple Indicators Approach James D. Adams and Mircea Marcu NBER Working Paper No. 10474

May 2004

JEL No. O31, O32, O38

\section{$\underline{\text { ABSTRACT }}$}

This paper reexamines the limits of the firm in Research and Development (R\&D). Using evidence drawn from industrial laboratories we study the causes and effects of R\&D sourcing. We begin with the causes of sourcing, finding that Research Joint Ventures (RJVs), the option to purchase and acquire, and research with federal government contribute to sourced R\&D. We then consider the effects of sourcing, RJVs, and the firm's internal research on innovation, as defined by patents and new products. Our results are that sourcing has little effect on innovation, but that RJVs and internal research increase innovation. This suggests specialization: cost saving is the primary motivation for sourcing, while innovation is the primary motivation for RJVs and internal research. Therefore, shared R\&D comes in several varieties: R\&D sourcing is not concerned with innovation, but consistent with their purpose, RJVs are instrumental in jointly commercializing the research of different firms.

James D. Adams

Department of Economics

3504 Russell Sage Laboratory

Rensselaer Polytechnic Institute

$1108^{\text {th }}$ Street

Troy, NY 12180-3590

and NBER

adamsj@rpi.edu

Mircea Marcu

Department of Economics

224 Matherly Hall

University of Florida

Gainesville, FL 32611-7140 


\section{Introduction}

The trading or pooling of research across firm boundaries determines the limits of the firm in $\mathrm{R} \& \mathrm{D}$, and so is a likely factor in the productive efficiency of industrial research. In this paper we revisit this topic using evidence from U.S. industrial research laboratories. In the case of R\&D sourcing, where the evidence is relatively detailed, we examine the causes that lie behind shared R\&D. In addition, we study the differing consequences for innovation, as defined by patents and new products, of two forms of shared R\&D: R\&D sourcing and Research Joint Ventures (RJVs).

The main results are that RJVs, the option to purchase and acquire, and research with federal government increase R\&D sourcing. Moreover, RJVs and the firm's internal research contribute to innovation. In contrast, $R \& D$ sourcing has no such effect. Therefore, internal research and shared R\&D are specialized: cost savings are the primary motive for R\&D sourcing, while invention and commercialization are the primary motive for internal research and RJVs. Taken together, the evidence suggests that $\mathrm{R} \& \mathrm{D}$ sourcing is neither concerned with, nor is it a threat to, intellectual property, even though RJVs, consistent with their purpose, are instrumental in jointly commercializing the research of different firms.

The subject is timely for several reasons. R\&D sourcing and RJVs have grown rapidly and play a more important role today than in the past ${ }^{1}$. In this paper $R \& D$ sourcing is primarily domestic, but it is similar to international sourcing of high-technology jobs. Such sourcing represents, besides evidence of comparative advantage, a source of disturbance to the labor markets of advanced countries that has awakened protectionist sentiments (Engardio, Bernstein, and Kripalani in Business Week: February 3, 2003; and "The Great Hollowing-Out Myth," The Economist: February 21, 2004). Our findings suggest that outsourcing of U.S. R\&D is cost saving, just as insourcing to the U.S. is, but that neither are likely to detract from intellectual property. The findings also suggest that international RJVs could be a useful vehicle for combining the research capabilities of firms in different countries.

\footnotetext{
${ }^{1}$ New R\&D partnerships in the MERIT-CATI database increased from 35 in 1970 to 150 in the late 1970s. From 1980 to 1990 new partnerships increased from 200 to 600. In the US CORE and NCRA-RJV databases, partnerships increased rapidly from 1985-1995, but decreased from 1996-1998, apparently due to a decline in the Advanced Technology Program, which supports cooperative R\&D. For details see Hagedoorn, Link, and Vonortas (2000). Also see Mowery (1992) for an overview of the motivations for international RJVs and other international cooperative research.
} 
R\&D sourcing could be related or unrelated to RJVs and other cooperative research. Under sourcing a firm pays other firms to do research (outsourcing) or else it is paid by them to do research (insourcing). Sourcing vests control with the outsourcing firm, but this need not rule out R\&D by a contractor on problems of common interest. Under a stable long term relationship between firms outsourced research could evolve into cooperative $R \& D$, because the scale of the sourced R\&D would support the contractor's investment in knowledge. This is unlikely to hold for transitory sourcing, since its scale and duration are inadequate to sustain such investments.

In this paper we consider several measures of R\&D sourcing as well as an indicator of RJVs². Some of the sourcing indicators could reflect durable partnerships and co-investment by partner firms, but others might not. Since we are unsure about the relationship between sourcing and jointly conducted R\&D we let the data decide whether sourcing is or is not relevant to innovation.

The empirical work is based on 220 industrial R\&D laboratories observed during 1991-1996. 115 parent firms in the chemicals, machinery, electrical equipment, and motor vehicles industries own these laboratories. Principal findings are the following. First, indicators of sentiment in favor of RJVs and Merger \& Acquisition (M\&A) are driving forces behind sourcing. This result implies that joint research and ownership motives contribute to sourcing.

Second, we find that interactions with federal government promote sourcing ${ }^{3}$. This result could be due to several policies. For example, the National Cooperative R\&D Act of 1984 relaxed antitrust stringency towards RJVs, while the National Cooperative Research and Production Act of 1993 extended similar protection to joint production of products derived from RJVs. Cooperative Research and Development Agreements (CRADAs) with federal laboratories have also subsidized cooperative research. The Advanced Technology Program favors cooperative research as a means of sharing the risks of new technologies. And finally, the Small Business Innovation Research Program (SBIR) supports technologyintensive startups, which could promote cooperative research with larger firms.

A third finding is that outsourcing and insourcing are concentrated in different segments of this paper's sample of R\&D laboratories. Outsourcing is sponsored by large laboratories whose skill-intensity

\footnotetext{
${ }^{2}$ The evidence on R\&D sourcing and its causes is more elaborate than the evidence on RJVs.

${ }^{3}$ Leyden and Link (1999) argue that RJVs which involve federal labs include a larger number of partners. This factor limits the loss of appropriability due to "open knowledge" policies of the federal labs, by diminishing appropriability to begin with, and selectively enables large partnerships to form.
} 
is average, at least by the standards of industrial research. On the contrary, we find that insourcing laboratories tend to be smaller and more skill-intensive than average.

Fourth, we find evidence of two types of R\&D outsourcing in the data. One type is financed directly from R\&D budget. This type consists of minor expenditures that are sensitive to laboratory size, to growth and volatility of the firm's sales, and to the supply of partner firms in the local area. The other type consists of "guest engineering" by partner firms, which is unrelated to R\&D budget. This other type of outsourcing is major, less localized, and more permanent than outsourcing directly from budget.

Fifth, patents and new products depend on internal R\&D but not sourcing. An indicator of RJVs does, however, contribute to new products. The focus of internal R\&D is intellectual property creation, whereas the focus of sourcing is on cost saving. This probably reflects deliberate strategy. Firms protect intellectual property by outsourcing less sensitive $R \& D$ and by assigning internal $R \& D$ to invention. RJVs are a means of jointly commercializing research, in which firms share R\&D resources to this end.

The rest of the paper is arranged as follows. Section II reviews the literature on the limits of the firm in R\&D. Section III sets forth models of R\&D sourcing and RJVs. Section IV discusses data sources and presents descriptive tables and graphs. Section IV examines the causes and consequences of R\&D sourcing and RJVs. A summary and discussion of policy implications is contained in section V.

\section{Review of the Literature}

\section{A. The Boundaries of the Firm}

Coase (1937) views the limits of the firm as determined by production costs inside the firm as compared with the costs of using the market, including transactions costs. In Williamson (1985) the transactions costs are partly attributed to supplier hold-ups after customers have invested in relationshipspecific assets. Thus, internal hierarchies are more advantageous when hold-up problems are more costly. In this way Transactions Cost Economics argues that bargaining costs expand firm boundaries ${ }^{4}$.

Grossman and Hart (1986) formulate a theory of vertical integration that includes benefits as well as costs. Their theory assumes that contracts cannot be fully specified, and emphasizes the scarcity of

\footnotetext{
${ }^{4}$ See Joskow (1987) for an empirical analysis of proxies for holdup problems, investment and contract duration in coal markets.
} 
ownership incentives for remedying incomplete contracts. Because of this, more ownership should be awarded to a firm as the value of its marginal product increases. Since awarding more ownership to one firm weakens the other's incentives, integration is not costless. Indeed, non-integration can be more efficient if firms are comparably productive. Property Rights Economics emphasizes the proper allocation of incentives by means of the optimal level of integration, so as to establish the solution closest to first best.

Holmstrom and Roberts (1998) critique both theories. They show that investment incentives depend on factors beside ownership, that holdup problems could be exaggerated, and that firm boundaries respond to more than investment incentives. For example, the incentives of Japanese auto suppliers depend on long-term relationships instead of ownership ${ }^{5}$. The key is repeat business, which punishes poor performance with a loss of future business. This is also a reason why holdup problems are exaggerated.

Abraham and Taylor (1996) explore the effect of industry seasonality and cyclicality on labor outsourcing. Using firm level data they find that cyclicality discourages outsourcing. Outsourcing does not buffer the labor force against uncertainty. Instead cost saving is the primary motive for labor outsourcing.

The broad conclusion from the literature is that firm boundaries are determined by transactions costs, limits of the firm's resources, ownership incentives, agency problems, and cost savings from outside contractors. Firm boundaries are the result of many considerations rather than one.

\section{B. The Limits of the Firm in R\&D}

Arrow's (1962) Paradox of Information asserts that buyers of information cannot know its value before possessing it—after the information has been sold at little or no cost. The Paradox explains why information sharing between firms is limited. Kogut and Zander (1992) agree that costs of information transfer between firms are intentionally high, but stress that in addition firms can make the costs of internal knowledge transfer intentionally low. This gives firms an informational advantage compared with the market.

\footnotetext{
${ }^{5}$ Monteverde and Teece (1982) study a sample of auto parts used in Ford and GM cars. They demonstrate that more design-intensive parts are integrated within firms. However this approach has since been replaced by outsourcing, accompanied by long term relationships with suppliers.
} 
Partial solutions to Arrow's Paradox have been found, since cooperative R\&D and information sharing do occur ${ }^{6}$. Mansfield, Schwartz, and Wagner (1981) find that imitation costs are $2 / 3$ of original innovation costs. Even with the help of the transferring firm, Teece (1977) finds that costs of international technology transfer are $1 / 5$ of project expense. Arora (1996) suggests that transactions costs can be advantageous to the owner provided that knowledge transfer is bundled with engineering and training.

Link (1983) studies the proportion of technological advance that is internal to the firm. He finds that firm size and diversification increase the internal proportion. This result is consistent with the resourcebased explanation for R\&D collaboration, since diversified firms have less demand for outside R\&D.

Pisano (1990) explores outsourcing in biotechnology. He finds that R\&D outsourcing declines when the number of suppliers is small, reflecting bargaining costs; the firm's focus on pharmaceuticals, because the firm's assets are self-sufficient; and experience in biotechnology, also a sign of self-sufficiency.

Motivations behind RJVs are discussed in Kogut (1991). Firms would like to expand into new markets but demand is uncertain. Starting an RJV offers the option to expand as well as to share risk. Because parties to the venture have different capabilities, the RJV reduces cost as well as risk ${ }^{7}$.

Mowery (1992) examines the growth of international collaborative ventures. He attributes their rise to increasing technological capabilities of overseas partners, to an increase in non-tariff barriers, and to rising costs and risks associated with bringing new products to market.

Aghion and Tirole (1994) analyze the issue of who should own the innovation, a customer or a research unit. As in Grossman and Hart (1986), ownership depends on comparative marginal products of the two parties. Allocation of the property right is always efficient when the research unit is the owner, but it might not be efficient when the customer is the owner. This is because the research unit may be cashconstrained and unable to buy the innovation.

Mowery (1995) explores the role of policy in setting limits on the firm's R\&D. For much of the $20^{\text {th }}$ century antitrust discouraged horizontal mergers, encouraged diversification, and expanded the limits of the firm in R\&D. Court decisions protected patent licenses and allowed firms to accumulate patent portfolios. Only after 1980 did increasing leniency of antitrust spur de-conglomeration, and reduce demand for R\&D. Thus antitrust and patent policies have shaped the limits of the firm in R\&D over long periods.

\footnotetext{
${ }^{6}$ Von Hippel (1988) gives examples of information sharing between firms in the same line of business.

${ }^{7}$ Consistent with this, Link (1988) finds that mergers are more important in R\&D-intensive industries.
} 
Several studies have examined the governance of cooperative R\&D. Oxley (1997) argues that barriers to the appropriation of intellectual property result in RJVs that are legally distinct from parent firms. Mowery, Oxley and Silverman (1998) studies firm alliances in light of the technological overlap between firms. The effect of overlap is U-shaped: firms that are too similar or too dissimilar gain little from working together. Azoulay (2003) examines clinical trials conducted by pharmaceutical firms. While volatility of sales is found to increase outsourcing, larger firms are less responsive to shocks, since they can buffer research groups by reassignment. Bizan (2003) examines American-Israeli research alliances. He finds that technical and commercial success increases when firms are related through ownership, when firms have complementary capabilities, and when projects are larger and last longer.

This brief survey has uncovered a range of benefits from sourcing and cooperative R\&D. Overall, though, the gains reduce to (1) cost saving, (2) benefits from combining complementary R\&D; and (3) the option to acquire and expand that is opened up by cooperative R\&D.

\section{Analytical Framework}

In this section we present simple models of the private gains from $R \& D$ sourcing and joint ventures. The arrangements differ in governance and purpose. Sourcing is integrated: the controlling firm gains from any intellectual property (IP) that results, examples of which are patents and new products. Even so, the firm faces a significant risk: its stock of IP could leak out more readily to partners if sourced R\&D is IPrelated. If this is so, then we might observe specialization: internal R\&D would contribute to IP creation, while sourcing would be cost-saving. On the contrary, RJVs are non-integrated and jointly controlled by firms, and their reason for being is innovation. Thus, built-in incentives of RJVs restrict damage from loss of IP and contribute to sharing of IP. As a consequence we are more certain that RJVs contribute to the formation of IP. The models presented below reflect this balance of considerations.

\section{A. Gains from R\&D Sourcing}

R\&D outsourcing could increase the value of the firm in two ways. It could add to the firm's stock of IP and to the discounted present value of its revenues, or it could lower the firm's R\&D costs. In this section we examine the two motives and their implications for sourcing. 
We begin with the intellectual property motive. Let $V(K)$ be the discounted present value of the firm's revenues, which depends on intellectual capital $K$. To ensure concavity of profits, we assume that $V(K)$ is concave: $V^{\prime}>0, V^{\prime \prime}<0$. Also firm R\&D $E_{K}$, and perhaps outsourced R\&D $e_{K}$ increase $K$ but are subject to diminishing returns. Thus $K$ is a concave function $K=G\left(E_{K}, e_{K}\right)$ such that $G_{1}>0, G_{2} \geq 0$ and $G_{i i}<0, G_{i j}>0, G_{11} G_{22}-G_{12}^{2}>0{ }^{8}$. Prices of $E_{K}$ and $e_{K}$ are $p_{E}$ and $p_{e}$.

We can allow for a richer set of effects of $e_{K}$ on $K$. There is the possibility, raised above, that sourcing could detract from IP because of information leakages (Arrow's Paradox of Information). If so, then $G_{2} \leq 0$, and this would rule out sourcing for the joint creation of intellectual property. This would limit the motive for sourcing to cost saving and not innovation. To emphasize this alternative motivation, we assume that internal and outsourced $R \& D$ are perfect substitutes in cost saving. To ensure concavity of the profit function we let the present value of the firm's costs $C$ be a convex function of the sum of the firm's cost saving R\&D $E_{C}$ and outsourced R\&D $e_{C}$. Then the firm's costs are $C=F\left(E_{C}+e_{C}\right)$ with $F^{\prime}<0, F^{\prime \prime}>0$. Together the profit function is

$$
\pi=V\left[G\left(E_{K}, e_{K}\right)\right]-F\left(E_{C}+e_{C}\right)-p_{E}\left(E_{K}+E_{C}\right)-p_{e}\left(e_{K}+e_{C}\right)
$$

First order conditions for a maximum of (1) are

$$
\begin{aligned}
& V^{\prime} G_{1}-p_{E} \leq 0 \\
& V^{\prime} G_{2}-p_{e} \leq 0 \\
& F^{\prime}-p_{E} \leq 0 \\
& F^{\prime}-p_{e} \leq 0
\end{aligned}
$$

Even if $G_{2} \leq 0$, so that $e_{K}=0$, the firm can still innovate, so that $K=G\left(E_{K}, 0\right)>0$. In this case outsourcing contributes nothing to $K$. Suppose further that $p_{e}<p_{E}$, so that outsourced R\&D is cheaper than internal R\&D. Since $E_{C}$ and $e_{C}$ are perfect substitutes this implies that $e_{C}>0, E_{C}=0$. Under such conditions internal R\&D specializes in IP creation, while outsourced $R \& D$ specializes in cost saving.

\footnotetext{
${ }^{8}$ We are assuming that the firm can innovate on its own so that $G\left(E_{K}, 0\right)>0$.
} 
Though the result is sensitive to the assumed conditions, difficulties of appropriating IP combined with less costly external R\&D would conduce to specialization.

Insourcing is readily introduced by including $R\left(E_{I}\right)-p_{E} E_{I}$ in (1). Since $R\left(E_{I}\right)$ is the present value of the return to insourcing and $p_{E} E_{I}$ is its cost, the difference is the net gain from insourcing. If $R\left(E_{I}\right)$ is concave then the first order condition $R^{\prime}-p_{E} \leq 0$ maximizes profits from insourcing. Nothing in this setup rules out simultaneous insourcing and outsourcing, which we in fact observe.

\section{B. Gains from Research Joint Ventures}

We conclude with an analysis of the gains from RJVs. This builds on Aghion and Tirole (1994) and Adams, Chiang, and Jensen (2003). The analysis illustrates the sharpness of the differences between sourcing and RJVs for innovation. Consider an RJV comprised of two firms. Let $E_{J}$ and $e_{J}$ stand for R\&D efforts of the firms with prices $p_{E}$ and $p_{e}$ as before. Again suppose that each firm can innovate on its own. The firm in question generates a base value of innovation of $B_{E}\left(E_{J}\right)$ and the other a base value of $B_{e}\left(e_{J}\right)$. An RJV improves on this by combining complementary capabilities of the firms. We represent this by assuming that joint research generates incremental IP with a value of $I\left(E_{J}, e_{J}\right)$. The value of the RJV equals the sum of the base and incremental values:

$$
V=B_{E}\left(E_{J}\right)+B_{e}\left(e_{J}\right)+I\left(E_{J}, e_{J}\right)
$$

The base values $B_{j}$ are concave so that $B^{\prime} j>0, B_{j}^{\prime \prime}<0, \mathrm{j}=\mathrm{E}$, e. The incremental value increases in $E_{J}$ and $e_{J}$ so that $I_{E}>0, I_{e}>0$. We assume that this to be concave so that $I_{E E}<0, I_{e e}<0$, and $I_{E E} I_{e e}-I_{E e}^{2}>0 . E_{J}$ and $e_{J}$ are complements so $I_{E e}>0$. We further assume that positive incremental value requires positive $E_{J}$ and $e_{J}: I\left(0, e_{J}\right)=I\left(E_{J}, 0\right)=I(0,0)=0$.

If the firms proceed independently then each firm maximizes $B_{i}-p_{i} E_{i}$ for which the solution is $E_{J}=E_{J}^{*}, e_{J}=e^{*}{ }_{J}, I(0,0)=0$. The base values $B_{E}$ and $B_{e}$ play the role of bargaining points while $I$ is the surplus from the RJV. The net value of the RJV is thus $V-p_{E} E_{J}-p_{e} e_{J}$. In the renegotiation 
phase firms share the surplus 50:50 and maximize their net private gains. The gain for the firm in question is $B_{E}+\frac{1}{2} I-p_{E} E$ while the gain for the other is $B_{e}+\frac{1}{2} I-e$. First order conditions are

$$
\begin{aligned}
& B_{E}^{\prime}+\frac{1}{2} I_{E} \leq p_{E} \\
& B_{e}^{\prime}+\frac{1}{2} I_{e} \leq p_{e}
\end{aligned}
$$

Equation (4) yields $E_{J}=\hat{E}_{J}>E *{ }_{J}$ and $e_{J}=\hat{e}_{J}>e^{*}{ }_{J}$. R\&D effort increases over the independent case because of complementarity of the efforts in $I$. This is despite the fact that the sharing of $I$ in (4) limits R\&D effort to levels that are less than first-best. We turn now to the empirical analysis.

\section{Data and Descriptive Analysis}

\section{A. Collection Procedures}

The empirical work is based on a 1997 survey of industrial R\&D laboratories (Adams, 1997) ${ }^{9}$. The survey concerns interactions of the laboratories with the rest of the firm and with external research organizations. The time period is 1991-1996. The sample includes 220 laboratories owned by 115 firms in the chemicals, machinery, electrical equipment, and motor vehicle industries ${ }^{10}$. Twenty-nine of the firms were less than 20 years old in 1997, so that young companies as well as old are in the sample. Respondents are experienced industrial $R \& D$ managers whose average tenure with the firm is 15 years.

The sample represents a $37 \%$ response rate from a population of 600 laboratories owned by 200 firms. The 200 companies were randomly drawn from 500 firms in chemicals (including pharmaceuticals and biotechnology), machinery (including computers), electrical equipment (including semiconductors), and motor vehicles. Firms had to be in Standard and Poor's 1995 Compustat database (Standard and Poor, 1995), had to report R\&D expenditures and sales, and had to name-match with assignees in the U.S. Patent and Trademark Office (USPTO) database. Thus the population consists of publicly traded firms in the four industries whose size, ratio of R\&D to sales, and patents were known. A response bias analysis finds no significant difference between sample and population means for sales, $R \& D$, or R\&D intensity ${ }^{11}$.

\footnotetext{
${ }^{9}$ Other papers that have used this data include Adams, Chiang, and Starkey (2001), Adams (2002), Adams, Chiang and Jensen (2003), and Adams (forthcoming).

${ }^{10}$ The distribution of the laboratories by industry of the parent firm is chemicals, $30.3 \%$; machinery, $25.0 \%$; electrical equipment, $27.9 \%$; and motor vehicles, $16.9 \%$.

${ }^{11}$ See Adams, Chiang, and Jensen (2003) for details of the response bias analysis.
} 
The data have some advantages. They report several measures of sourcing as well as an indicator of Research Joint Ventures (RJVs). Included are percentages of R\&D budget both outsourced and insourced, and of percentages of engineering hours contributed to new products by customers and suppliers. Finally, the data include a dummy indicator of the importance of RJVs. Moreover, the causes as well as consequences of R\&D sourcing can be explored, since the data include a large number of laboratory characteristics that could identify the separate relationships.

The data also have limitations. The sourcing indicators are collected at the laboratory level and are an average across contracts. The indicator of the importance of RJVs is a subjective assessment across all RJVs of the laboratory, for which we lack good instruments. Data are largely missing on partner firms, and any remaining information on partners represents the laboratory’s point of view.

\section{B. Description of the Principal Variables}

This paper is concerned with the limits of the firm in R\&D. To this end, the survey includes four measures of R\&D sourcing. The first two are percentages of R\&D budget outsourced and insourced ${ }^{12}$. The data are time-varying since they are collected in 1991 and 1996. The second two measures capture "offbudget" outsourcing. These are percentages of engineering hours that customers and suppliers contribute to new products ${ }^{13}$. These "guest engineering" variables apply to the entire period 1991-1996 and are time-

${ }^{12}$ The question on percentage of R\&D budget outsourced is as follows:

“Check the percent of your laboratory's R\&D budget for 1991 and 1996 conducted for your laboratory by other firms. Fill in "Other" if the percent exceeds those listed.

\section{Budget Percent 1991}

1. None

2. $0.1-1 \%$

3. $2-3 \%$

4. $4-5 \%$

5. $6-7 \%$

6. Other $\%$

\begin{tabular}{ll}
$i$ & $i$ \\
$i$ & $i$ \\
$i$ & $i$ \\
$i$ & $i$ \\
\hline
\end{tabular}

The question on percentage of R\&D budget insourced is almost the same:

“Check the percent of your laboratory's R\&D budget for 1991 and 1996 conducted by your laboratory for other firms. ..."

${ }^{13}$ The question on customer impact on customer contributions to new products is as follows: 
invariant. The variety of sourcing indicators is useful. The same laboratory reports insourcing and outsourcing, so that behavior can be compared. Also, engineering hours complement the percent of R\&D budget outsourced, since such in-kind contributions are compensated differently. In addition contributors of guest engineering are customers and suppliers, which are often long-term partners of a firm.

In addition to sourcing variables the data include a dummy indicator equal to 1 if RJVs are important to the laboratory and 0 otherwise. The data contain no other measures of RJVs, such as their size, number, and duration. However the RJV dummy does capture relevance of joint research, which as we have seen could have different implications than sourcing and internal research.

Also included is a dummy indicator of the importance of mergers and acquisition (M\&A). This equals 1 if M\&A activity is important and 0 otherwise. Kogut (1991) suggests that RJVs provide a real option for expansion which is correlated with M\&A sentiments . To test this idea we conducted a $2 \times 2$ contingency table test of the independence of the RJV and M\&A dummies. The hypothesis of independence is rejected at greater than the one percent level of significance ${ }^{14}$. For this reason we combine the RJV and M\&A dummies in a composite RJV-M\&A indicator.

In addition the survey records industrial technologies that are important sources of technology transfer to the laboratory. The number of important technologies is

$$
S T=\sum_{i=1}^{N} t_{i}
$$

In (5), $t_{i}=1$ if technology $i$ is an important source of technology transfer and 0 otherwise. In the empirical work we compute the logarithm of (5) and treat it as a motive for sourcing and joint ventures.

Other data include laboratory R\&D budget (in millions of 1987 dollars) and the fraction of the laboratory's science and engineering workforce composed of PhDs or MDs. These variables, which are

"On a typical product improvement or new product, what percent of engineering hours are provided by customers? Circle one.

$\begin{array}{ccccc}\text { None } & 0.1-10 \% & 11-25 \% & 26-40 \% & 41-70 \% ” \\ \mathbf{1} & \mathbf{2} & \mathbf{3} & \mathbf{4} & \mathbf{5}\end{array}$

The question on supplier impacts is the same except for a slight difference in wording:

"On a typical product improvement or new product, what percent of engineering hours are provided by suppliers? Circle one...."

${ }^{14}$ The $\chi^{2}$ test statistic is $\chi^{2}=7.9$ with a P-value of 0.005 . 
collected in both 1991 and 1996, capture size and skill intensity of the laboratory. The survey also reports 1991 and 1996 counts of the number of patents and new products introduced ${ }^{15}$. These variables serve as innovation indicators. Of course, not all laboratories answered these questions and some of the laboratories are not engaged in new products. We impute missing values on patents using U.S. Patent and Trademark Office data matching the firm, two-digit Zip Code of the laboratory and year. But no such imputation can be carried out for new products. This limits sample size in any analysis that uses this variable.

The federal government has promoted cooperative R\&D in several ways. It has favored cooperative research directly through CRADAs and the Advanced Technology Program. It has subsidized cooperative research by setting aside federal R\&D for small businesses under the SBIR program, since small firms could turn to large firms for their R\&D. It has protected cooperative research from antitrust under the National Cooperative R\&D Act of 1984 and the National Cooperative Research and Production Act of 1993. And finally, the defense department seems to have favored cooperative R\&D, perhaps because of the complexity of its technologies.

The survey reports interactions with government that could capture some of these effects. These include the number of closely affiliated federal laboratories, a dummy indicator of the importance of defense technologies, and dummy indicators of the importance of Cooperative Research and Development Agreements (CRADAs) and the Small Business Innovation Research Program (SBIR).

We test for the possibility that CRADA and SBIR are related, because of a "dual use" motivation for CRADAs, as a means of satisfying the SBIR set-aside requirement. A $2 \times 2$ contingency table test

\footnotetext{
${ }^{15}$ The question on the number of patents is as follows:
}

"How many U.S. patents were granted to your laboratory during 1991 and $1996 ?$

Number of U.S. patents granted

The question on the number of new products reads as follows:

"How many new products did your laboratory introduce during 1991 and $1996 ?$ 
decisively rejects independence of CRADA and SBIR at more than the one percent level ${ }^{16}$. For this reason we utilize a composite CRADA-SBIR dummy indicator through much of the analysis.

Besides the survey data we constructed growth and volatility of parent firm sales using Compustat $^{17}$. Both variables are derived from the firm-level regression,

$$
\ln \left(\text { sales }_{i}\right)=\beta_{0 i}+\beta_{1 i} \bullet \text { year }+u_{i}
$$

The regression yields an estimate of $\beta_{1 i}$, the growth rate of the firm's sales. In addition the procedure estimates the volatility of sales, in the form of $\sigma_{i}$-the root mean-squared error of the regression. In the text we refer to $\sigma_{i}$ as the standard deviation of the logarithm of sales.

We expect $\beta_{1 i}$ to increase sourcing. Faster growth might raise the firm's value as a partner, or it could increase the firm's demand for contract research to stay on track with its growth objectives. The effect of higher volatility $\sigma_{i}$ on sourcing is unclear. It could signify the meager appeal of an unstable business (Abraham and Taylor, 1996). Alternatively, $\sigma_{i}$ could represent a buffering motive, which favors outsourcing because it protects the firm's R\&D from fluctuations (Azoulay, 2003).

We constructed the logical intersection of the firm's primary industry with the set of important technologies using both Compustat and the survey. Overlap is defined as

$$
\text { Overlap }=\frac{\sum_{i=1}^{N} d_{i} t_{i}}{\sum_{i=1}^{N} t_{i}}=\frac{\sum_{i=1}^{N} d_{i} t_{i}}{S T}
$$

In (7), $d_{i}$ is a dummy equal to 1 and 0 otherwise, if a technology is included in the parent firm's primary industry. The numerator equals the number of technologies that are both sources of technology transfer and are included in the firm's industry. The denominator is the unconditional number of technologies that are sources of technology transfer. It follows that Overlap must lie between 0 and 1. Overlap may capture substitution of technologies inside the firm for technologies outside the firm.

\footnotetext{
${ }^{16}$ The test statistic for independence is $\chi^{2}=36.3$, with a P-value of 0.000 , less than one-tenth of one percent. ${ }^{17}$ Survey firms have non-missing data on sales in 1995 Compustat data. In the case of a few firms less than 10 years of data exist on their sales.
} 
Finally we constructed indicators of the diversity and size of local industry. For this purpose we obtained data on employment by two-digit industry for each of the 77 Standard Metropolitan Statistical Areas (SMSAs) where the laboratories reside. We took these data from the 1992 Censuses of Construction, Manufacturing, Utilities, Wholesale Trade, Retail Trade; Finance, Insurance, and Real Estate, and Services, which cover nearly all of private industry in an SMSA. The immediate source is U.S. Bureau of the Census (1998). Using this evidence we constructed Diversity of employment in an SMSA:

$$
\text { Diversity }=1-H=1-\sum_{i=1}^{n} s_{i}^{2}
$$

Diversity equals one minus the Herfindahl index $(\mathrm{H})$ of employment concentration among industries in an SMSA, in which $S_{i}$ is the employment share of an industry in an area. To see that (8) does measure diversity, notice that $\mathrm{H}$ equals 1 and Diversity equals 0 if all employment is found in one industry. When employment is the same across industries, $\mathrm{H}$ equals $1 / n$. Diversity equals $(n-1) / n$, and approaches 1.0 if $n$ were to increase without bound. A more diverse SMSA could supply more partners for sourcing. To separate Diversity from size we include the logarithm of employment in the SMSA as well.

Table 1 reports means and standard deviations of the variables. The table shows that 1.6 percent of R\&D budget is outsourced, while 1.7 percent is insourced. The standard deviation of insourcing is 7.4 percent. This exceeds the standard deviation of outsourcing, 4.0 percent, because of the greater skew of insourcing.

The proportion of $\mathrm{R} \& \mathrm{D}$ budget outsourced is small. However, outsourcing is much larger that takes the form of engineering hours provided by customers and suppliers. Mean customer and supplier percentages, which equal 4.8 and 7.2 percent respectively, imply that 12 percent of engineering hours are contributed by partner firms. Assume that the engineering percentages are fully representative of other R\&D inputs contributed by partners. Then the findings on guest engineering suggest that outsourcing which is "off-budget" is on the order of 12 percent of total R\&D costs ${ }^{18}$. This is about ten times greater than outsourcing directly from R\&D budget (12 percent versus 1.6 percent).

\footnotetext{
${ }^{18}$ Jankowski (1993) finds that labor costs are 42 percent of R\&D cost, and that 25 percent of R\&D cost consists of engineering wages. While we lack information on the other 75 percent of outsourced R\&D, it seems likely that other expenditures would move in tandem with engineering hours and wages. The reason is that the R\&D production process is similar in different firms, especially those in the same industry.
} 
In addition, 69 percent of the laboratories view RJVs as important, 50 percent view mergers and acquisitions as important, and 81 percent view the RJV-M\&A combined interaction as important. The mean number of important technologies equals 9.2, with a standard deviation of $5.4^{19}$.

The mean R\&D budget of the laboratories is 14 million dollars of 1987. The standard deviation is 41.8 million dollars, indicating the enormous skew of laboratory size ${ }^{20}$. On average, 13 percent of the laboratory science and engineering workforce consists of $\mathrm{PhDs}$ or MDs.

We turn next to measures of association with federal government. The mean number of closely affiliated federal laboratories is 1.2 . Its standard deviation is 2.9 , which indicates concentration of federal laboratory linkages in a sub-sample of the data. Eight percent of industrial laboratories regard defense technologies as important to their $\mathrm{R} \& \mathrm{D}$, so that defense linkages in this sample are rare. A third of the laboratories regard CRADAs or the SBIR program as important.

The rest of the table describes variables for the firm and locality. Mean growth of sales is six percent, while the standard deviation of the logarithm of sales is 20 percent. Mean Overlap equals 25 percent, so that a fourth of the technologies are "spanned" by the firm's technologies. Mean Diversity is 0.94 with a standard deviation of 0.03 . Thus employment concentration is low and diversity is high. This reflects city size: the average SMSA employs 1.3 million persons in 1992.

\section{Distribution of the Sourcing Indicators}

Figure 1 is a line graph of the marginal distributions of the percent of R\&D budget outsourced and insourced. The percentages are grouped in intervals of $0 \%, 0-1 \%, 3-6 \%$, and $6 \%+$. The frequencies are almost monotonically declining, with a slight upturn for the highest valued category, caused by aggregation above the $6 \%$ cutoff. The modal value for sourcing is $0 \%$. More laboratories report this value for insourcing than for outsourcing.

Figure 2 is a bar graph of the joint distribution of sourcing from R\&D budget. Since the data thin out in two dimensions, we aggregate all percentages above a 1\% cutoff. Figure 2 shows that outsourcing and insourcing are positively correlated. For example, frequency of $0 \%$ values of insourcing decrease from

\footnotetext{
${ }^{19}$ The potential number of technologies is 102 , so the mean value of 9.5 indicates selectivity in the technologies that are important sources of technology transfer to the laboratory.

${ }^{20}$ Laboratory expenditures range from 0.1 million to over 400 million dollars of 1987.
} 
back to front as the outsourcing percent increases, and the same is true of outsourcing. In the Ordered Probit analysis we estimate the correlation of the error terms across the two sourcing equations.

Figure 3 is a line graph of the percent of engineering hours contributed to new products by customers and suppliers. The categories are $0 \%, 0-10 \%, 10-25 \%, 25-40 \%$, and $41 \%^{+}$. The modal value is $0-10 \%$ rather than $0 \%$, suggesting that customer and supplier outsourcing are more important than outsourcing directly from budget. Also, the distribution of supplier engineering hours lies to the right of customer engineering hours, indicating a greater contribution by suppliers. This is partly due to the presence in the sample of motor vehicles, for which supplier R\&D is common.

Figure 4 is a two-dimensional bar graph of the joint distribution of customer and supplier engineering hours. An increase in supplier engineering brings about a rightward shift of the distribution of customer engineering. The converse is true for supplier engineering. The Ordered Probit analysis below again takes this positive correlation into account by means of the same SUR methodology as above.

Table 2 tests for independence of the various indicators using the $2 \times 2$ contingency table test. Panel A rejects independence of R\&D budget outsourced and insourced at a P-value that is less than one percent. Panel B rejects independence of engineering hours contributed by customers and suppliers at a similar level of significance. In summary, there is strong evidence that the sourcing indicators are positively correlated.

\section{Findings}

Having completed the description of the data, we turn next to the econometric analysis. The section begins with equations that explain percentages of $R \& D$ budget outsourced and insourced. Afterwards we discuss equations that explain percentages of engineering hours contributed by customers and suppliers. In both cases the estimation method is bivariate Ordered Probit. This is a Maximum Likelihood procedure which is analogous to SUR. It is required because the sourcing indicators are measured in increasing intervals and are positively correlated ${ }^{21}$. The section concludes with an analysis of the role of sourcing, RJVs, and internal research in the generation of patents and new products.

Before presenting the results, we would like to comment on the problem of assessing the effect of a group of variables across several tables. Since we have quite a few dependent variables, the results will

\footnotetext{
${ }^{21}$ See Greene (2000), chapter 19, section 19.8 for a discussion of the Ordered Probit likelihood function. Adams (2002b) documents the bivariate extension of this. The program is available on request.
} 
inevitably vary. This leads us to engage in implicit averaging of the results. For example, if the only statistically significant effects of federal government linkages are to increase R\&D sourcing, we simply say that linkages to federal government increase sourcing without dwelling on the details.

\section{A. Determinants of Sourcing from R\&D Budget}

Percentages of R\&D budget outsourced and insourced are the dependent variables in table $3^{22}$.

The data are a panel that includes the years 1991 and 1996. For this reason we include a dummy equal to 1 if the year is 1996 and 0 otherwise to capture changes in sourcing propensities. However, this variable is not significant. The industry dummies are likewise insignificant and are omitted from the table. Taking missing values into consideration, the table includes 227 observations and 115 laboratories.

As noted, the econometric method treats outsourcing and insourcing as a system. In support of this the estimated cross-equation correlations are positive and highly significant. The likelihood ratio $\chi^{2}$ statistics on the bottom line also show that as a group, the independent variables are highly significant.

System A consists of equations 3.1 and 3.2 and is our baseline specification. Joint housing with manufacturing is positive and significant in the insourcing equation. One possibility is that sourcing proxies for R\&D exchange within firms. We test for this possibility, but end up rejecting it. For example, we do not find a significant effect on sourcing of frequency of meetings with production and R\&D managers in the rest of the firm. Instead joint housing with manufacturing suggests the applied character of the laboratory: more applied laboratories are more likely to source their R\&D.

The RJV-M\&A indicator increases sourcing in both directions. This is consistent with the role of sourcing as an indicator of joint research and acquisition. We are unclear as to the role of the number of important technologies. This could stand for complexity and the demand for outsourcing, and yet it has no effect on outsourcing. Alternatively, the number of technologies captures the scope of R\&D laboratories that insource R\&D. The logarithm of laboratory R\&D increases outsourcing but not insourcing, suggesting that larger laboratories are more likely to outsource R\&D. The fraction of the workforce

\footnotetext{
${ }^{22}$ The percentages of R\&D budget sourced are coded as follows: if the proportion sourced equals $0 \%$, then the variable equals 1 ; if the proportion sourced lies between $0-1 \%$ then the variable equals 2 ; if the proportion lies between $2-3 \%$ then the variable equals 3 ; and if the proportion is $4+\%$ then the variable equals 4 . The categories are chosen to avoid small numbers of observations in the different cells.
} 
comprised of PhDs increases insourcing, but does not affect outsourcing, suggesting that insourcing laboratories are more skill intensive than average.

Together the findings indicate that $\mathrm{PhD}$-intensive laboratories that use many technologies are more likely to insource. In contrast, larger laboratories outsource a larger fraction of their R\&D regardless of $\mathrm{PhD}$ intensity and the number of technologies. A comparison of the findings on outsourcing and insourcing suggests a division of labor in which large laboratories outsource to small, highly skilled laboratories. Sourcing is also the result of working jointly with other groups, perhaps to acquire or to be acquired by them.

We conclude 3.1 and 3.2 with a discussion of firm level effects in the sourcing equations. Growth increases sourcing while volatility discourages it. The result on volatility clashes with the notion that outsourcing buffers R\&D teams from uncertainty, since outsourcing would increase with volatility if this were true ${ }^{23}$. Overlap of the firm's primary industry with outside technologies reduces sourcing. This implies that technologies inside the firm substitute for outside technologies.

System B consists of equations 3.3 and 3.4. The specification adds interactions with federal government to 3.1 and 3.2. The interactions include the number of closely affiliated government laboratories and the importance of defense technologies to the laboratory. The number of government laboratories may increase contract work and thus insourcing. Defense affiliations may increase outsourcing because of complexity of military technologies or policy. But interactions with federal government are significant only for insourcing. Equations 3.3 and 3.4 also include characteristics of the locality. Diversity of employment increases sourcing, perhaps by increasing the number of specialist firms in an SMSA.

Equations 3.5 and 3.6 add the number of firms that are influential for laboratory research to 3.3 and 3.4. Outside firms appear to become influential by virtue of outsourced R\&D, since there is no effect on insourcing.

Table 4 adds indicators of federal policies towards R\&D to 3.5 and 3.6. Included are dummy indicators of the importance of the SBIR program and Cooperative R\&D Agreements (CRADAs) with

\footnotetext{
${ }^{23}$ The findings on the volatility of sales resemble those found by Abraham and Taylor (1996) for labor outsourcing. In their paper, industry seasonality and cyclicality also discourage outsourcing.
} 
federal laboratories, both separately and together. CRADA contributes to insourcing, suggesting the creation of contract research for federal laboratories. SBIR is never significant ${ }^{24}$.

Table 5 also pivots off 3.5 and 3.6. The table varies the specification of the combined RJV-M\&A indicator. In 5.1 and 5.4 RJV is entered by itself. RJV is significant for outsourcing. RJV and M\&A are introduced separately in 5.2 and 5.5. Merger and acquisition matter for outsourcing but not insourcing. In 5.3 and 5.6 we enter the sum of M\&A and RJV. This is more significant than the individual indicators, suggesting that it is difficult to separate the RJV and M\&A motives for sourcing.

\section{B. Determinants of Engineering Hours Outsourced}

Table 6 reports bivariate Ordered Probit equations where the dependent variable is the percentage of engineering hours contributed to new products by customers and suppliers ${ }^{25}$. Since the percentages are time-invariant, the data form a cross-section of 158 laboratories after missing values are taken into account. Since customer and supplier engineering are positively correlated, we treat the two equations as a system that takes the cross-equation correlation of the error terms into account. The estimated correlations are positive and highly significant in table 6.

System A consists of equations 6.1 and 6.2. The supplier equation includes a dummy indicator if the primary industry of the parent firm is in motor vehicles. This is significant at the one percent level, consistent with the importance of supplier R\&D in this industry. Coefficients of other industry dummies are not significant and are omitted.

The RJV-M\&A indicator significantly increases engineering hours contributed by customers, but has no effect on supplier engineering. In this sample, favorable sentiment towards joint research concentrates on customer sourcing. The fraction of the laboratory's workforce that holds the PhD strongly reduces engineering hours outsourced, perhaps because a skilled labor force replaces outsourcing.

Since the dependent variables measure customer and supplier contributions we test for their consistency by including independent measures of customer and supplier impact. Equation 6.1 includes an

\footnotetext{
${ }^{24}$ Adams, Chiang and Jensen (2003) find that CRADAs are the primary mechanism by which federal laboratories affect patents and company-financed R\&D of industrial laboratories.

${ }^{25}$ Engineering hours contributed by customers and suppliers are coded as follows: if engineering hours equal 0 percent, then the variable equals 1 ; if engineering lies between 0 and 10 percent, then the variable equals 2; and if engineering hours equal 11 percent or more, then the variable equals 3 . These categories are chosen to avoid small numbers of observations in the different cells.
} 
indicator of the importance of direct contact with customers. Customers contribute more engineering when direct contact with them is important. Equation 6.2 includes an indicator of the importance of direct contact with suppliers, supplier problem solving, and long term relations with suppliers. Suppliers perform more engineering when their contributions are viewed as important.

We conclude 6.1 and 6.2 with interactions with federal government. The interactions increase engineering by customers but not by suppliers. Equations 6.3 and 6.4 replace the number of government laboratories with the SBIR-CRADA indicator. The consistent finding in this sample is that federal government interactions promote customer, but not supplier engineering.

Guest engineering in table 6 behaves differently from budget outsourced in table 3. Laboratory size matters for budget outsourced but not engineering; SBIR and CRADAs matter for engineering but not budgetary outsourcing; skill level decreases guest engineering but not budget outsourced; and influential firms increase budget outsourced but not guest engineering. Other differences are that growth of the firm, the volatility of firm sales, and Overlap do not affect engineering hours, though they do affect percent of budget outsourced. Furthermore, employment and Diversity in the SMSA have little relevance to customer and supplier engineering. For this reason we have dropped indicators of the firm and locality from table 6 .

Clearly guest engineering is distinct from $R \& D$ budget outsourced. Besides being larger, guest engineering represents long-term relationships with partner firms. This could explain why engineering hours are less tied to the local SMSA, less closely associated with trend and volatility of sales, and more of a substitute for skills within the laboratory. This interpretation also suggests that outsourcing from $R \& D$ budget is transitory and is designed to smooth the pace of $R \& D$ projects.

The next two tables report variations in the SBIR-CRADA and RJV-M\&A variables. Table 7 reports findings using alternative specifications of the SBIR-CRADA indicator. CRADA but not SBIR matters in these data and the intensive form of CRADA-SBIR is more significant than either variable taken separately. This influence is again restricted to customers. Table 8 considers alternative specifications of the RJV-M\&A dummy indicator. The intensive form of RJV-M\&A alone is significant, suggesting as before, that it is quite hard to separate joint research from acquisition. 


\section{Sourcing, RJVs, Internal Research, and Innovation}

Table 9 concludes the empirical work. In this table we examine determinants of patents and new products produced by the laboratory. The estimation method is Negative Binomial regression, or random effects Poisson regression ${ }^{26}$. Poisson regression is relevant because the data are count data whose mean is close to zero. The random effects specification is still better than the Negative Binomial because the variance exceeds the mean. This creates "over-dispersion" that Poisson regression cannot address.

Equations 9.1 and 9.3 report baseline estimates of the patent and new product equations. All the equations include year and industry dummies, the RJV-M\&A indicator, laboratory R\&D budget, and R\&D in the rest of the firm. The time dummy is significant in the new product equations but not the patent equations, which indicates rapid growth of commercialized innovation. Industry effects are significant: patents are less common in pharmaceuticals and biotechnology, but are more common in electrical equipment than the omitted industry (machinery). The RJV-M\&A indicator contributes to an increase in new product introductions ${ }^{27}$. Laboratory R\&D consistently increases patents and new products. R\&D in the rest of the firm contributes to patents but not new products. This suggests that spillovers from other firm R\&D are restricted to pre-commercial invention.

Equations 9.2 and 9.4 change the specification slightly. We assign the midpoint of the sourcing intervals to the fractions outsourced and insourced and divide laboratory R\&D into three parts. These are amounts outsourced and insourced, and the remainder, internal laboratory R\&D. We take logarithms of the three components, entering them as separate variables ${ }^{28}$. Internal $R \& D$ alone increases patents and new products. Since sourced $R \& D$ does not produce intellectual property, the alternative hypothesis is that it saves R\&D cost. All the effects are consistent with the specialization hypothesis that we express formally in section III. The positive sign of the RJV-M\&A indicator for new products but not patents suggests that joint research aims at commercialization but not invention.

\footnotetext{
${ }^{26}$ Hausman, Hall and Griliches (1984) derive fixed and random effects estimators for the analysis of count data. Greene (2000), chapter 19, section 19.9 is a survey of this literature.

${ }^{27} \mathrm{We}$ are unable to carry out a two-equation analysis where the RJV indicator is endogenous, because we lack instruments that would identify the separate relationships.

${ }^{28}$ We add 0.001 (a thousand dollars) to each $R \& D$ variable to handle zeroes before taking logarithms.
} 
Equations 9.3 and 9.6 replace sourcing from R\&D budget with percents of engineering hours contributed by customers and suppliers. Like the previous sourcing indicators, these have no effect on patents or new products, again suggesting that the role of R\&D sourcing is to save costs.

\section{Conclusion}

This paper has explored causal factors behind R\&D sourcing, as well as the consequences for innovation of sourcing, RJVs, and internal firm research using data from a sample of R\&D laboratories. The principal findings are that RJVs, the option to acquire and expand, and interactions with federal government are driving forces behind sourcing. In addition we find that patents and new products stay the same as sourcing increases. This supports the hypothesis that sourcing saves $R \& D$ costs and secures needed technical services, but has little to do with innovation. In contrast, internal research and RJVs significantly increase innovation. The divergent effects of RJVs and sourcing on innovation suggest that firm-firm R\&D interactions have multiple purposes as well as diverse effects.

The findings have several policy implications. To begin with, federal policy seems to have succeeded in promoting sourcing and other cooperative research. For another, any fears that international outsourcing of R\&D could compromise intellectual property appear to be misplaced: sourced R\&D has little to do with innovation. And finally, based on our findings, RJVs appear to be a useful form of international cooperative R\&D. This is due to the incentives which these arrangements set in place to combine intellectual assets of firms in different countries.

Sourcing and RJVs reflect a division of labor in industrial research. Because of this, future work might explore efficiency gains in R\&D from this division of research effort. If, as the sourcing results imply, the primary effect is cost saving, then sourcing allows industrial R\&D to be scaled back at the same level of innovation. But if, as the RJV indicator suggests, more products result from combining capabilities of firms and organizations, then cooperative research expands innovation using the same R\&D resources. It is not clear which gain is the larger of the two. 
Table 1

Descriptive Statistics, Study of R\&D Sourcing and Joint Ventures

\begin{tabular}{|c|c|c|}
\hline Variable & Mean & S.D. \\
\hline \multicolumn{3}{|l|}{ R\&D Sourcing, RJV, and M\&A Indicators } \\
\hline \multicolumn{3}{|l|}{ Percent of R\&D Budget Sourced } \\
\hline Percent of Laboratory R\&D Budget Outsourced ${ }^{\mathrm{a}, \mathrm{b}}$ & 1.57 & 3.95 \\
\hline Percent of Laboratory R\&D Budget Insourced ${ }^{\mathrm{a}, \mathrm{b}}$ & 1.67 & 7.42 \\
\hline \multicolumn{3}{|l|}{ Percent of Engineering Hours Contributed by Partner Firms } \\
\hline $\begin{array}{l}\text { Percent of Engineering Hours on New and Improved Products } \\
\text { Contributed by Customers }\end{array}$ & 4.84 & 7.93 \\
\hline $\begin{array}{l}\text { Percent of Engineering Hours on New and Improved Products } \\
\text { Contributed by Suppliers }{ }^{b}\end{array}$ & 7.19 & 8.65 \\
\hline \multicolumn{3}{|l|}{$R J V-M \& A$ Indicators } \\
\hline RJVs Important to the Laboratory ( 1 if yes, 0 if no) & 0.69 & 0.47 \\
\hline M\&A Important to the Laboratory ( 1 if yes, 0 if no) & 0.50 & 0.50 \\
\hline RJVs-M\&A Important to the Laboratory ( 1 if yes, 0 if no) & 0.81 & 0.40 \\
\hline \multicolumn{3}{|l|}{ Determinants of R\&D Sourcing, Patents, and New Products } \\
\hline \multicolumn{3}{|l|}{ Characteristics of the Laboratory } \\
\hline $\begin{array}{l}\text { Number of Technologies that are Important Sources of Technology Transfer to } \\
\text { the Laboratory }\end{array}$ & 9.15 & 5.41 \\
\hline 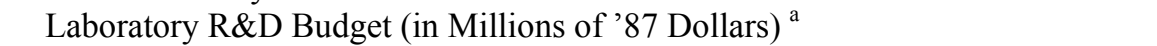 & 14.01 & 41.75 \\
\hline $\begin{array}{l}\text { PhDs or MDs as a Fraction of the Laboratory's Science and Engineering } \\
\text { Workforce }^{\text {a }}\end{array}$ & 0.13 & 0.17 \\
\hline Number of Closely Affiliated Government Laboratories & 1.17 & 2.90 \\
\hline Defense Technologies Important to the Laboratory & 0.08 & 0.28 \\
\hline SBIR Program or CRADAs Important (1 if yes, 0 if no) ${ }^{c}$ & 0.33 & 0.47 \\
\hline \multicolumn{3}{|l|}{ Characteristics of the Parent Firm and Area } \\
\hline $\begin{array}{l}\text { Standard Deviation of the Logarithm of Parent Firm Sales } \\
\text { (in Millions of ' } 87 \text { Dollars) }\end{array}$ & 0.20 & 0.18 \\
\hline Rate of Growth of Parent Firm Sales (in Millions of '87 Dollars) & 0.06 & 0.09 \\
\hline $\begin{array}{l}\text { Overlap of Parent Firm's Industry with the Number of Technologies that are } \\
\text { Important Sources of Technology Transfer to the Laboratory }\end{array}$ & 0.25 & 0.25 \\
\hline Diversity of Employment in the Laboratory's Metropolitan Area & 0.94 & 0.03 \\
\hline Employment in the Laboratory's Metropolitan Area (in millions) & 1.27 & 1.32 \\
\hline
\end{tabular}

Notes: Data sources are the Survey of Industrial Laboratory Technologies 1996, Standard and Poor's Compustat, and the U.S. Bureau of the Census. ' Data are collected in 1991 and 1996 and hence are timevarying. ${ }^{b}$ The midpoint of each interval has been assigned to the variable. ${ }^{c}$ SBIR stands for the Small Business Innovation Research program, which sets aside a portion of the budget of federal agencies to support small businesses. CRADA stands for Cooperative Research and Development Agreements, which result from another set-aside. In this case part of federal laboratory budget is earmarked for in-kind research conducted jointly with firms. 
Table 2

$2 \times 2$ Contingency Table Tests

For Independence of the R\&D Sourcing Indicators

Panel A. R\&D Budget Outsourced and Insourced

\begin{tabular}{|c|c|c|}
\hline & R\&D Budget Insourced $=0$ & R\&D Budget Insourced $>0$ \\
\hline R\&D Budget Outsourced $=0$ & $\mathrm{~N}=97$ & $\mathrm{~N}=14$ \\
\hline & Pct $=40.1$ & Pct $=5.8$ \\
\hline R\&D Budget Outsourced $>0$ & $\mathrm{~N}=71$ & $\mathrm{~N}=60$ \\
\hline Chi-Square Test, P-Value & \multicolumn{2}{|c|}{$\chi^{2}=31.2 *, P=0.000$} \\
\hline
\end{tabular}

Panel B. Customer and Supplier Engineering Hours

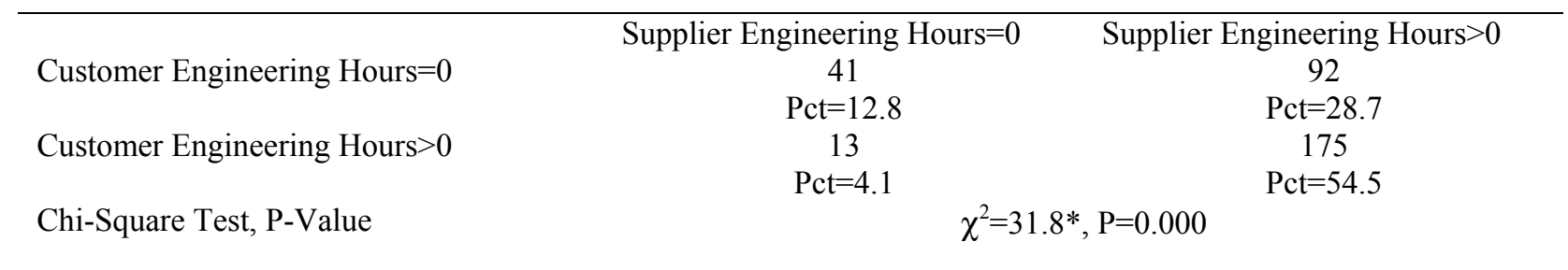

Notes: Data source is the Survey of Industrial Laboratory Technologies 1996. * The null hypothesis of independence is rejected at more than the $1 \%$ level of significance. 
Table 3

Determinants of R\&D Budget Outsourced and Insourced

(Asymptotic Normal Statistics in Parentheses)

\begin{tabular}{|c|c|c|c|c|c|c|}
\hline \multirow[t]{2}{*}{ Variable or Statistic } & \multicolumn{2}{|c|}{$\begin{array}{c}\text { System A } \\
\text { Percent of R\&D Budget }\end{array}$} & \multicolumn{2}{|c|}{$\begin{array}{c}\text { System B } \\
\text { Percent of R\&D Budget }\end{array}$} & \multicolumn{2}{|c|}{$\begin{array}{c}\text { System C } \\
\text { Percent of R\&D Budget }\end{array}$} \\
\hline & $\begin{array}{c}\text { Outsourced } \\
\text { Eq. 3.1 } \\
\end{array}$ & $\begin{array}{c}\text { Insourced } \\
\text { Eq. } 3.2 \\
\end{array}$ & $\begin{array}{c}\text { Outsourced } \\
\text { Eq. 3.3 } \\
\end{array}$ & $\begin{array}{c}\text { Insourced } \\
\text { Eq. } 3.4 \\
\end{array}$ & $\begin{array}{c}\text { Outsourced } \\
\text { Eq. 3.5 } \\
\end{array}$ & $\begin{array}{c}\text { Insourced } \\
\text { Eq. } 3.6 \\
\end{array}$ \\
\hline Year Dummy & $\begin{array}{l}-0.08 \\
(-0.5)\end{array}$ & $\begin{array}{l}-0.07 \\
(-0.4)\end{array}$ & $\begin{array}{l}-0.08 \\
(-0.5)\end{array}$ & $\begin{array}{l}-0.08 \\
(-0.5)\end{array}$ & $\begin{array}{l}-0.08 \\
(-0.5)\end{array}$ & $\begin{array}{l}-0.08 \\
(-0.5)\end{array}$ \\
\hline \multicolumn{7}{|l|}{ Characteristics of the Laboratory } \\
\hline Laboratory is Jointly Housed with & 0.30 & 0.68 & 0.11 & 0.66 & 0.15 & 0.66 \\
\hline Manufacturing ( 1 if yes, 0 if no) & $(1.8)$ & $(3.4)^{* *}$ & $(0.6)$ & $(2.9)^{* *}$ & $(0.8)$ & $(2.9)^{* *}$ \\
\hline RJV-M\&A Important to the Laboratory & 0.64 & 0.84 & 0.69 & 0.96 & 0.68 & 0.95 \\
\hline ( 1 if yes, 0 if no) & $(2.6)^{* *}$ & $(2.8)^{* *}$ & $(2.7)^{* *}$ & $(3.1)^{* *}$ & $(2.7)^{* *}$ & $(3.0)^{* *}$ \\
\hline Log (Number of Technologies that are & 0.15 & 0.51 & 0.13 & 0.55 & 0.05 & 0.49 \\
\hline Sources of Technology Transfer) & $(1.1)$ & $(3.1)^{* *}$ & $(1.0)$ & $(3.2)^{* *}$ & $(0.4)$ & $(2.7)^{* *}$ \\
\hline Log (Laboratory R\&D Budget) & $\begin{array}{c}0.16 \\
(3.1)^{*}\end{array}$ & $\begin{array}{l}-0.02 \\
(-0.3)\end{array}$ & $\begin{array}{c}0.13 \\
(2.5)^{*}\end{array}$ & $\begin{array}{l}-0.08 \\
(-1.3)\end{array}$ & $\begin{array}{l}0.15 \\
(2.8)^{* *}\end{array}$ & $\begin{array}{l}-0.07 \\
(-1.1)\end{array}$ \\
\hline Fraction of Laboratory Scientists and & 0.41 & 2.22 & 0.39 & 2.07 & 0.23 & 1.95 \\
\hline Engineers Holding the PhD or MD Degree & $(0.8)$ & $(4.0)^{* *}$ & $(0.7)$ & $(3.5)^{* *}$ & $(0.4)$ & $(3.3)^{* *}$ \\
\hline Log (Number of Government Laboratories) & & & $\begin{array}{l}0.04 \\
(1.9)\end{array}$ & $\begin{array}{c}0.10 \\
(3.7)^{* *}\end{array}$ & $\begin{array}{l}0.02 \\
(0.8)\end{array}$ & $\begin{array}{l}0.08 \\
(3.0)^{* *}\end{array}$ \\
\hline Defense Technologies Important & & & 0.48 & -0.30 & 0.53 & -0.30 \\
\hline ( 1 if yes, 0 if no) & & & (1.6) & $(-0.9)$ & $(1.8)$ & $(-0.9)$ \\
\hline $\begin{array}{l}\text { Number of Outside Firms that are Influential } \\
\text { for Laboratory Research }\end{array}$ & & & & & $\begin{array}{l}0.13 \\
(2.5)^{*}\end{array}$ & $\begin{array}{l}0.07 \\
(1.4)\end{array}$ \\
\hline \multicolumn{7}{|l|}{ Characteristics of the Firm and Area } \\
\hline Rate of Growth in Firm Sales & $\begin{array}{l}1.77 \\
(1.8)\end{array}$ & $\begin{array}{l}1.93 \\
(1.8)\end{array}$ & $\begin{array}{l}2.59 \\
(2.5)^{*}\end{array}$ & $\begin{array}{l}2.76 \\
(2.5)^{*}\end{array}$ & $\begin{array}{c}2.23 \\
(2.1)^{*}\end{array}$ & $\begin{array}{c}2.57 \\
(2.3)^{*}\end{array}$ \\
\hline Standard Deviation in the Logarithm of Firm & -0.99 & -1.29 & -1.31 & -1.75 & -1.42 & -1.79 \\
\hline Sales & $(-1.8)$ & $(-1.9)$ & $(-2.3)^{*}$ & $(-2.5)^{*}$ & $(-2.5)^{*}$ & $(-2.5)^{*}$ \\
\hline Overlap of Firm's Industry with Technology & -0.90 & -0.03 & -0.83 & 0.32 & -1.07 & 0.19 \\
\hline Transfer to the Laboratory & $(-2.6)^{* *}$ & $(-0.1)$ & $(-2.2)^{*}$ & $(0.8)$ & $(-2.7)^{* *}$ & $(0.4)$ \\
\hline Diversity of Employment in the Laboratory's & & & 9.71 & 9.64 & 9.70 & 9.56 \\
\hline Metropolitan Area & & & $(2.7)^{* *}$ & $(2.2)^{*}$ & $(2.7)^{* *}$ & $(2.2)^{*}$ \\
\hline Log (Employment in the Laboratory's & & & 0.05 & 0.17 & 0.04 & 0.17 \\
\hline Metropolitan Area) & & & $(0.7)$ & $(2.1)^{*}$ & $(0.6)$ & $(2.0)^{*}$ \\
\hline \multicolumn{7}{|l|}{ Statistics of the Likelihood Function } \\
\hline Lower Cut Point & 0.71 & 2.82 & 10.22 & 13.94 & 10.12 & 13.79 \\
\hline Upper Cut Point & 1.59 & 3.56 & 11.15 & 14.75 & 11.07 & 14.62 \\
\hline Cross-Equation Correlation Coefficient & \multicolumn{2}{|c|}{$\begin{array}{c}0.41 \\
(4.7)^{* *}\end{array}$} & \multicolumn{2}{|c|}{$\begin{array}{c}0.36 \\
(3.8)^{* *}\end{array}$} & \multicolumn{2}{|c|}{$\begin{array}{c}0.34 \\
(3.5)^{* *}\end{array}$} \\
\hline Log Likelihood & \multicolumn{2}{|c|}{-383.3} & \multicolumn{2}{|c|}{-367.6} & \multicolumn{2}{|c|}{-364.1} \\
\hline Likelihood Ratio $\chi^{2}$ & \multicolumn{2}{|c|}{$41.8 * *$} & \multicolumn{2}{|c|}{$53.7 * *$} & \multicolumn{2}{|c|}{$57.7 * *$} \\
\hline
\end{tabular}

Notes: Principal data source is the Survey of Industrial Laboratory Technologies 1996. Estimation method is Ordered Probit. The data are a panel covering the years 1991 and 1996 since the sourcing indicators are time varying. The number of observations is $\mathrm{N}=227$. $* *$ Parameter is significantly different from zero at the $1 \%$ level for a one-tailed test. * Parameter is significantly different from zero at the $5 \%$ level for a one-tailed test. 
Table 4

Determinants of R\&D Budget Sourced, Variations on Interactions with Government (Asymptotic Normal Statistics in Parentheses)

\begin{tabular}{|c|c|c|c|c|c|c|}
\hline \multirow[b]{2}{*}{ Variable or Statistic } & \multicolumn{3}{|c|}{ Percent of R\&D Budget Outsourced } & \multicolumn{3}{|c|}{ Percent of R\&D Budget Insourced } \\
\hline & Eq. 4.1 & Eq. 4.2 & Eq. 4.3 & Eq. 4.4 & Eq. 4.5 & Eq. 4.6 \\
\hline SBIR Program Important & 0.09 & & & -0.24 & & \\
\hline (1if yes, 0 if no) & $(0.3)$ & & & $(-0.9)$ & & \\
\hline CRADAs Important & 0.11 & & & 0.70 & & \\
\hline ( 1 if yes, 0 if no) & $(0.6)$ & & & $(3.2)^{* *}$ & & \\
\hline $\begin{array}{l}\text { SBIR or CRADAs Important } \\
(1 \text { if yes, } 0 \text { if no) }\end{array}$ & & 0.23 & & & 0.57 & \\
\hline $\begin{array}{l}\text { SBIR + CRADAs Important } \\
\text { (range } 0 \text { to } 2 \text { ) }\end{array}$ & & & $\begin{array}{l}0.11 \\
(0.9)\end{array}$ & & & $\begin{array}{c}0.31 \\
(2.6)^{* *}\end{array}$ \\
\hline
\end{tabular}

Notes: Principal data source is the Survey of Industrial Laboratory Technologies 1996. The estimation method is Ordered Probit. The data are a panel covering the years 1991 and 1996 since the sourcing indicators are time varying. The number of observations is $\mathrm{N}=227$. Besides the government interactions shown, the equations are specified as in equations 3.5 and 3.6 of table 3 . **Parameter is significantly different from zero at the $1 \%$ level for a one-tailed test. *Parameter is significantly different from zero at the $5 \%$ level for a one-tailed test.

Table 5

Determinants of R\&D Budget Sourced, Comparative Role of Research Joint Ventures and Merger and Acquisition (Asymptotic Normal Statistics in Parentheses)

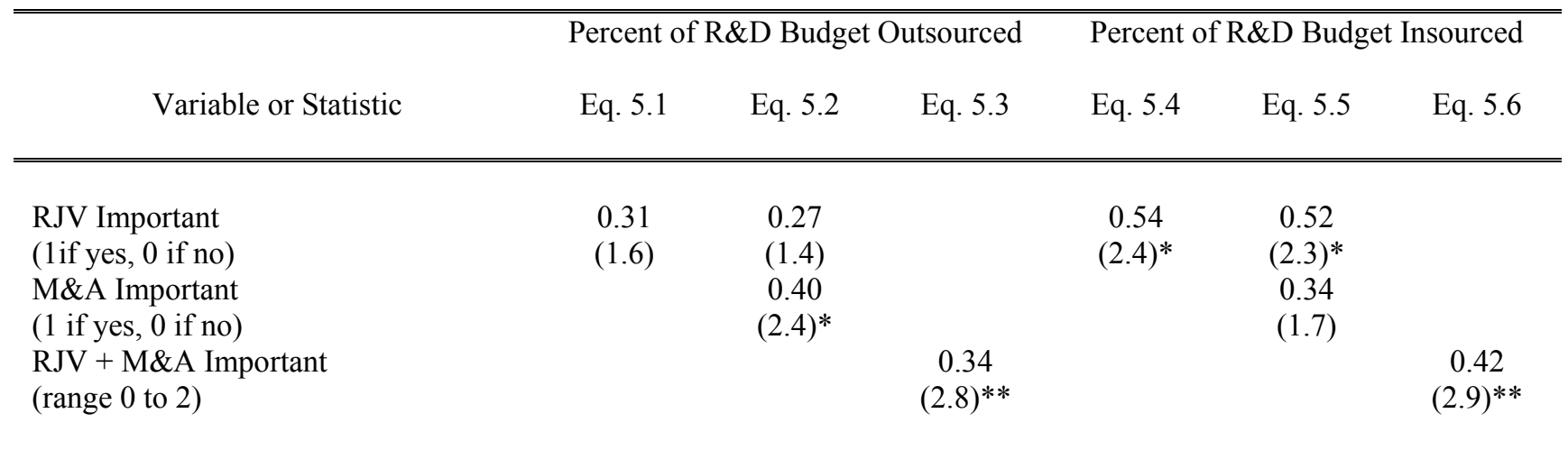

Notes: Principal data source is the Survey of Industrial Laboratory Technologies 1996. The estimation method is Ordered Probit. The data are a panel covering the years 1991 and 1996 since the sourcing indicators are time varying. The number of observations is $\mathrm{N}=227$. Besides the specification of the RJV and M\&A indicators, the equations are specified as in equations 3.5 and 3.6 of table 3 . ${ }^{*}$ Parameter is significantly different from zero at the $1 \%$ level for a one-tailed test. *Parameter is significantly different from zero at the $5 \%$ level for a one-tailed test. 
Table 6

Determinants of the Percent of Engineering Hours

Contributed by Customers and Suppliers to New Products

(Asymptotic Normal Statistics in Parentheses)

\begin{tabular}{|c|c|c|c|c|}
\hline \multirow{2}{*}{ Variable or Statistic } & \multicolumn{2}{|c|}{$\begin{array}{c}\text { System A } \\
\text { Percent of Engineering Hours } \\
\text { Contributed by }\end{array}$} & \multicolumn{2}{|c|}{$\begin{array}{c}\text { System B } \\
\text { Percent of Engineering Hours } \\
\text { Contributed by }\end{array}$} \\
\hline & $\begin{array}{c}\text { Customers } \\
\text { Eq. } 6.1\end{array}$ & $\begin{array}{l}\text { Suppliers } \\
\text { Eq. } 6.2\end{array}$ & $\begin{array}{c}\text { Customers } \\
\text { Eq. } 6.3\end{array}$ & $\begin{array}{c}\text { Suppliers } \\
\text { Eq. } 6.4\end{array}$ \\
\hline
\end{tabular}

\section{Characteristics of the Laboratory}

Parent Firm in Motor Vehicles

( 1 if yes, 0 if no)

RJV-M\&A Important to the Laboratory

( 1 if yes, 0 if no)

Log (Number of Technologies that are Sources

of Technology Transfer to the Laboratory)

Log (Laboratory R\&D Budget)

$\begin{array}{cccc} & 0.78 & & 0.74 \\ 0.74 & (2.9)^{* *} & & (2.8)^{* *} \\ (2.7)^{* *} & 0.39 & 0.69 & 0.37 \\ -0.18 & (1.5) & (2.5)^{*} & (1.4) \\ (-1.2) & 0.00 & -0.22 & -0.01 \\ -0.01 & (0.0) & (-1.4) & (-0.1) \\ (-0.2) & -0.05 & -0.03 & -0.07 \\ -2.62 & (-1.0) & (-0.4) & (-1.2) \\ (-3.9)^{* *} & -1.91 & -2.79 & -1.97 \\ 0.86 & (-3.3)^{* *} & (-4.1)^{* *} & (-3.3)^{* *} \\ (2.0)^{*} & & 0.88 & \\ & & (2.1)^{*} & \\ & 2.03 & & 1.99 \\ 0.08 & (2.7)^{* *} & & (2.6)^{* *} \\ (2.5)^{*} & & & \\ & 0.00 & & \\ 0.72 & (0.1) & & (1.1) \\ (2.0)^{*} & & 0.76 & -0.01 \\ -0.03 & 0.08 & (3.3)^{* *} & (-0.0) \\ (-0.4) & (0.2) & (2.0)^{*} & 0.08 \\ & 0.09 & -0.01 & (1.4)\end{array}$

Fraction of Laboratory Scientists and

Engineers Holding the PhD or MD Degree

Direct Contact with Customers Important

(1 if yes, 0 if no)

Direct Contact/Problem Solving/Long Term

Relations with Suppliers Important (1 if yes, 0

if no)

Log (Number of Government Laboratories)

SBIR or CRADAs Important

(1 if yes, 0 if no)

Defense Technologies Important

( 1 if yes, 0 if no)

Number of Outside Firms that are Influential

for Laboratory Research

$\begin{array}{cccccc}0.04 & & 1.14 & 0.50 & & 1.09 \\ 1.78 & & 3.09 & 2.27 & & 3.04 \\ & 0.39 & & & 0.37 & \\ & (3.9)^{* *} & & & (3.7)^{* *} & \\ -253.8 & & & -251.7 & \\ & & & & \\ & & & & \\ & & & & \\ & 38.1 * * & & & 41.2 * *\end{array}$

Likelihood Ratio $\chi^{2}$

$38.1^{* *}$

Lower Cut Point

Upper Cut Point

Cross-Equation Correlation Coefficient

Log Likelihood

Notes: Principal data source is the Survey of Industrial Laboratory Technologies 1996. The estimation method is Bivariate Ordered Probit. The data are a cross section that spans the period 1991-1996, since percent engineering hours variables are time-invariant. The number of observations is $\mathrm{N}=158$.

**Parameter is significantly different from zero at the $1 \%$ level for a one-tailed test. *Parameter is significantly different from zero at the $5 \%$ level for a one-tailed test. 
Table 7

Determinants of the Percent of Engineering Hours

Contributed by Customers and Suppliers to New Products, Variations on Interactions with Government (Asymptotic Normal Statistics in Parentheses)

\begin{tabular}{|c|c|c|c|c|}
\hline \multirow[t]{2}{*}{ Variable or Statistic } & \multicolumn{2}{|c|}{$\begin{array}{l}\text { Percent of Engineering Hours } \\
\text { Contributed by Customers }\end{array}$} & \multicolumn{2}{|c|}{$\begin{array}{l}\text { Percent of Engineering Hours } \\
\text { Contributed by Suppliers }\end{array}$} \\
\hline & Eq. 7.1 & Eq. 7.2 & Eq. 7.4 & Eq. 7.5 \\
\hline SBIR Program Important & 0.61 & & 0.51 & \\
\hline (1 if yes, 0 if no) & $(1.9)$ & & $(1.5)$ & \\
\hline CRADAs Important & 0.48 & & -0.00 & \\
\hline ( 1 if yes, 0 if no) & $(2.0)^{*}$ & & $(-0.0)$ & \\
\hline $\begin{array}{l}\text { SBIR + CRADAs Important } \\
\text { (range } 0 \text { to } 2 \text { ) }\end{array}$ & & $\begin{array}{c}0.5 \\
(3.3)^{* * *}\end{array}$ & & 0.19 \\
\hline
\end{tabular}

Notes: Principal data source is the Survey of Industrial Laboratory Technologies 1996. The estimation method is Ordered Probit. The data are a cross section that spans the years 1991-1996, since the percent engineering hours are time invariant. The number of observations is $\mathrm{N}=158$. Besides the government interactions as shown, the equations are specified as in equations 6.3 and.6.4 of table 6 . **Parameter is significantly different from zero at the $1 \%$ level for a one-tailed test. *Parameter is significantly different from zero at the $5 \%$ level for a one-tailed test.

Table 8

Determinants of the Percent of Engineering Hours Contributed by Customers and Suppliers to New Products, Comparative Role of Research Joint Ventures and Merger and Acquisition (Asymptotic Normal Statistics in Parentheses)

\begin{tabular}{|c|c|c|c|c|c|c|}
\hline \multirow[b]{2}{*}{ Variable or Statistic } & \multicolumn{3}{|c|}{$\begin{array}{c}\text { Percent of Engineering Hours } \\
\text { Contributed by Customers }\end{array}$} & \multicolumn{3}{|c|}{$\begin{array}{l}\text { Percent of Engineering Hours } \\
\text { Contributed by Suppliers }\end{array}$} \\
\hline & Eq. 8.1 & Eq. 8.2 & Eq. 8.3 & Eq. 8.4 & Eq. 8.5 & Eq. 8.6 \\
\hline RJV Important & 0.37 & 0.31 & & 0.04 & -0.08 & \\
\hline (1 if yes, 0 if no) & $(1.6)$ & $(1.3)$ & & $(0.2)$ & $(-0.4)$ & \\
\hline M\&A Important & & 0.33 & & & 0.60 & \\
\hline (1 if yes, 0 if no) & & $(1.6)$ & & & $(3.0)$ & \\
\hline RJV + M\&A Important & & & 0.32 & & & 0.30 \\
\hline (range 0 to 2 ) & & & $(2.3)^{*}$ & & & $(2.2)^{*}$ \\
\hline
\end{tabular}

Notes: Principal data source is the Survey of Industrial Laboratory Technologies 1996. The estimation method is Ordered Probit. The data are a cross section that spans the years 1991-1996, since the percent engineering hours are time invariant. The number of observations is $\mathrm{N}=158$. Besides the specification of the RJV and M\&A indicators, the equations are specified as in equations 6.3 and 6.4 of table 6 .

**Parameter is significantly different from zero at the $1 \%$ level for a one-tailed test. *Parameter is significantly different from zero at the $5 \%$ level for a one-tailed test. 
Table 9

Patents, New Products, Sourcing, and RJVs

(Asymptotic Normal Statistics in Parentheses)

\begin{tabular}{|c|c|c|c|c|c|c|}
\hline \multirow[t]{2}{*}{ Variable or Statistic } & \multicolumn{3}{|c|}{ Number of Patents } & \multicolumn{3}{|c|}{ Number of New Products } \\
\hline & Eq. 9.1 & Eq. 9.2 & Eq. 9.3 & Eq. 9.4 & Eq. 9.5 & Eq. 9.6 \\
\hline Year Dummy & $\begin{array}{l}0.16 \\
(1.0)\end{array}$ & $\begin{array}{l}0.16 \\
(0.9)\end{array}$ & $\begin{array}{l}0.15 \\
(0.9)\end{array}$ & $\begin{array}{l}0.37 \\
(2.3)^{*}\end{array}$ & $\begin{array}{l}0.35 \\
(2.1)^{*}\end{array}$ & $\begin{array}{c}0.36 \\
(2.2)^{*}\end{array}$ \\
\hline Parent Firm in Chemicals & -0.09 & -0.06 & -0.00 & 0.31 & 0.26 & 0.30 \\
\hline ( 1 if yes, 0 if no) & $(-0.4)$ & $(-0.2)$ & $(-0.0)$ & $(1.2)$ & $(1.0)$ & $(1.1)$ \\
\hline Parent Firm in Biotechnology or & -0.95 & -0.90 & -0.86 & -0.32 & -0.33 & -0.16 \\
\hline Pharmaceuticals ( 1 if yes, 0 if no) & $(-3.0)^{* *}$ & $(-2.8)^{* *}$ & $(-2.6)^{* *}$ & $(-1.2)$ & $(-1.2)$ & $(-0.6)$ \\
\hline Parent Firm in Electrical Equipment & 0.65 & 0.69 & 0.73 & 0.44 & 0.53 & 0.46 \\
\hline ( 1 if yes, 0 if no) & $(2.8)^{* *}$ & $(2.9)^{* *}$ & $(3.0)^{* *}$ & $(1.8)$ & $(2.2)^{*}$ & $(1.9)$ \\
\hline Parent Firm in Motor Vehicles & -0.29 & -0.25 & -0.57 & -0.10 & -0.04 & -0.11 \\
\hline ( 1 if yes, 0 if no) & $(-1.0)$ & $(-0.9)$ & $(-1.9)$ & $(-0.3)$ & $(-0.2)$ & $(-0.4)$ \\
\hline RJV-M\&A Important to the Laboratory & 0.29 & 0.29 & 0.14 & 0.58 & 0.62 & 0.42 \\
\hline ( 1 if yes, 0 if no) & $(1.1)$ & $(1.1)$ & $(0.5)$ & $(2.2)^{*}$ & $(2.3)^{*}$ & $(1.5)$ \\
\hline Log (Laboratory R\&D Budget) & $\begin{array}{c}0.70 \\
(13.7)^{* *}\end{array}$ & & $\begin{array}{c}0.73 \\
(13.6)^{* *}\end{array}$ & $\begin{array}{c}0.51 \\
(9.9)^{* *}\end{array}$ & & $\begin{array}{c}0.51 \\
(9.7)^{* *}\end{array}$ \\
\hline Log (Laboratory R\&D Budget Outsourced) & & $\begin{array}{l}-0.02 \\
(-0.6)\end{array}$ & & & $\begin{array}{l}-0.08 \\
(-1.8)\end{array}$ & \\
\hline Log Laboratory R\&D Budget Insourced) & & $\begin{array}{l}0.02 \\
(0.6)\end{array}$ & & & $\begin{array}{l}0.02 \\
(0.2)\end{array}$ & \\
\hline Log (Internal Laboratory R\&D Budget) & & $\begin{array}{c}0.71 \\
(12.4)^{* *}\end{array}$ & & & $\begin{array}{c}0.56 \\
(9.4)^{* *}\end{array}$ & \\
\hline $\log (\mathrm{R} \& \mathrm{D}$ in the Rest of the Firm) & $\begin{array}{c}0.08 \\
(4.6)^{* *}\end{array}$ & $\begin{array}{c}0.08 \\
(4.8)^{* *}\end{array}$ & $\begin{array}{c}0.07 \\
(4.2)^{* *}\end{array}$ & $\begin{array}{l}-0.01 \\
(-0.5)\end{array}$ & $\begin{array}{l}-0.00 \\
(-0.1)\end{array}$ & $\begin{array}{l}-0.01 \\
(-0.5)\end{array}$ \\
\hline $\begin{array}{l}\text { Percent of Engineering Hours Contributed to } \\
\text { New Products by Customers }\end{array}$ & & & $\begin{array}{l}-0.98 \\
(-0.9)\end{array}$ & & & $\begin{array}{l}0.60 \\
(0.5)\end{array}$ \\
\hline Percent of Engineering Hours Contributed to & & & -0.81 & & & -0.07 \\
\hline New Products by Suppliers & & & $(-0.6)$ & & & $(-0.1)$ \\
\hline Log Likelihood & -630.4 & -629.1 & -566.6 & -468.5 & -466.8 & -450.9 \\
\hline Likelihood Ratio $\chi^{2}$ & $213.1 * *$ & $215.8 * *$ & $192.6^{* *}$ & $121.6^{* *}$ & $125.0^{* *}$ & $116.2 * *$ \\
\hline Number of Observations & 242 & 242 & 221 & 178 & 178 & 168 \\
\hline
\end{tabular}

Notes: Principal data source is the Survey of Industrial Laboratory Technologies 1996. The estimation method is Negative Binomial Regression. The data are a panel covering the years 1991 and 1996 since the patent and new product indicators are time-varying. *Parameter is significantly different from zero at the $1 \%$ level for a one-tailed test. ** Parameter is significantly different from zero at the $5 \%$ level for a onetailed test. 

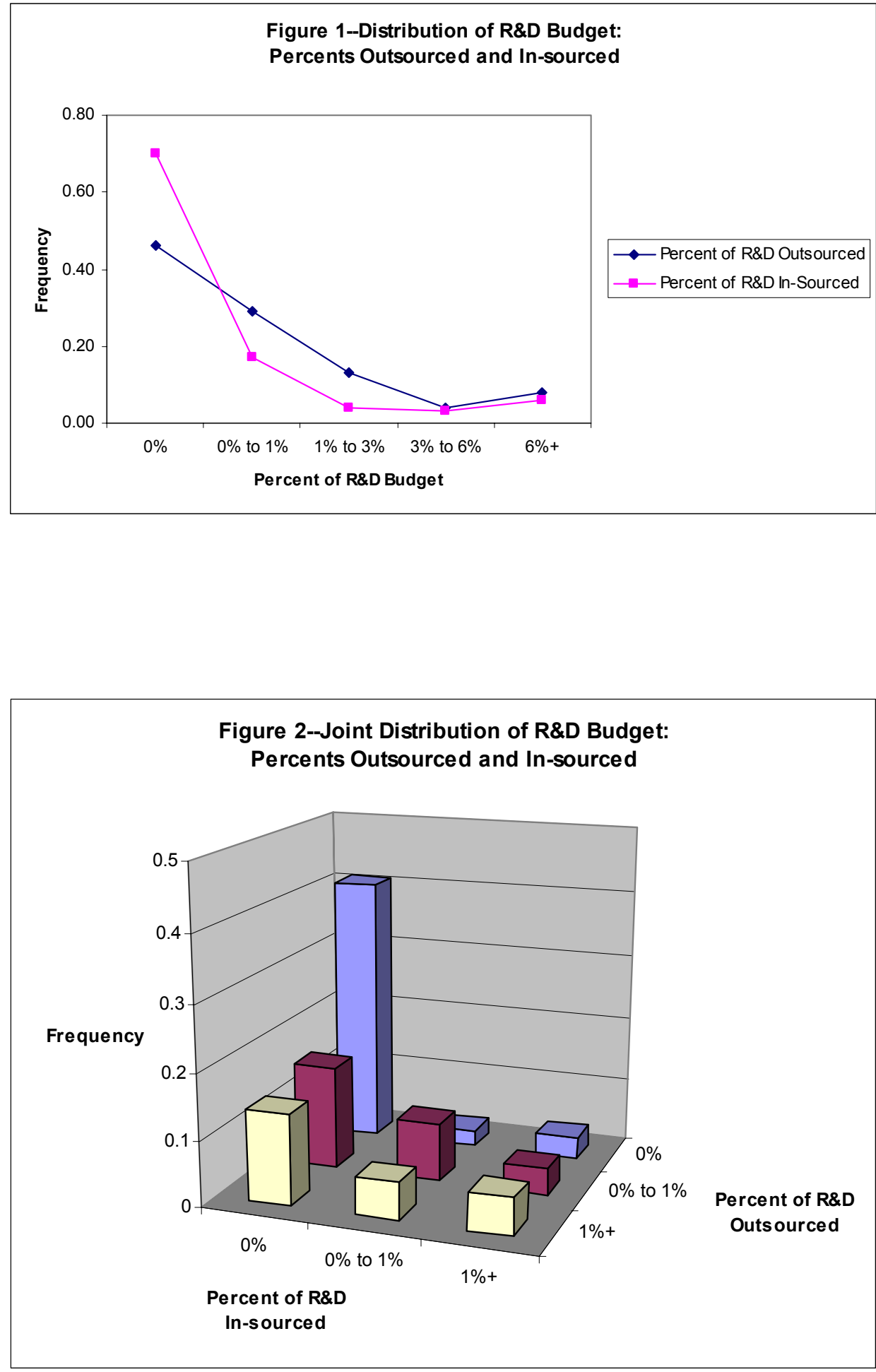

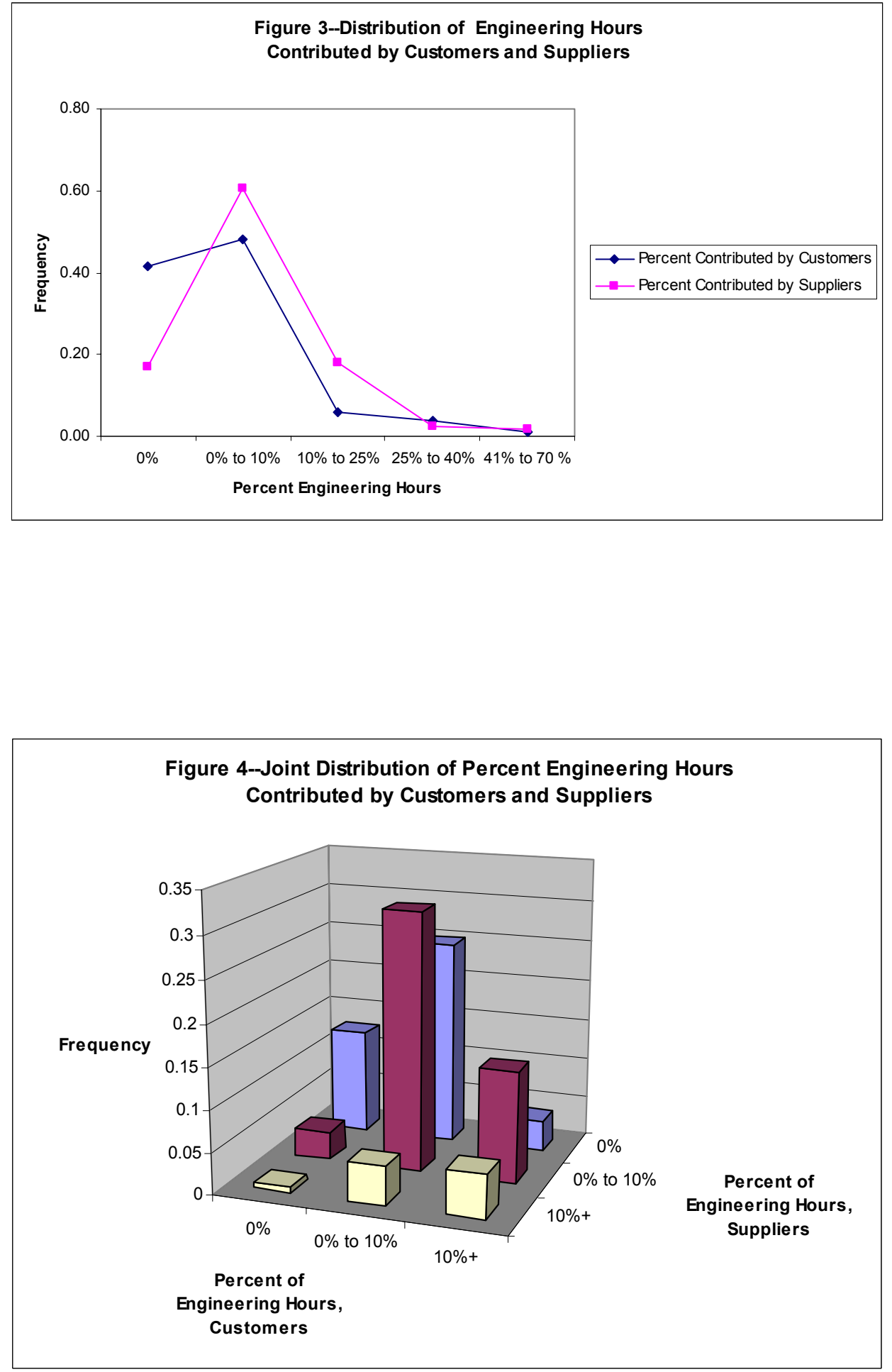


\section{References}

Abraham, Katherine G., and Susan K. Taylor, “Firms’ Use of Outside Contractors: Theory and Evidence,”

Journal of Labor Economics 14 (July 1996): 394-424.

Adams, James D., Survey of Industrial Laboratory Technologies 1996, Department of Economics, University of Florida: 1997. , "Comparative Localization of Academic and Industrial Spillovers," Journal of

Economic Geography 2 (July 2002a): 253-278.

, "Learning, Internal Research, and Spillovers: Evidence from a Sample of R\&D

Laboratories," forthcoming in The Economics of Innovation and New Technology. , Eric P. Chiang, and Katara Starkey, "Industry-University Cooperative Research

Centers,” Journal of Technology Transfer 26 (January 2001): 73-86.

, Eric P. Chiang, and Jeffrey L. Jensen, "The Influence of Federal Laboratory R\&D on

Industrial Research,” The Review of Economics and Statistics 85 (November 2003): 1003-1020.

Aghion, Philippe, and Jean Tirole, “The Management of Innovation,” Quarterly Journal of Economics 109 (November 1994): 1185-1210.

Arora, Ashish, "Contracting for Tacit Knowledge: the Provision of Technical Services in Technology Licensing Contracts,” Journal of Development Economics 50 (1996): 233-256.

Arrow, Kenneth J., "Economic Welfare and the Allocation of Resources for Invention," in R.R. Nelson, Editor, The Rate and Direction of Economic Activity: Economic and Social Factors, Princeton, New Jersey: Princeton University Press for the National Bureau of Economic Research, 1962.

Azoulay, Pierre, “Acquiring Knowledge Within and Across Firm Boundaries: Evidence from Clinical Development," Cambridge, Massachusetts: NBER Working Paper 10083, November 2003.

Bizan, Oded, “The Determinants of Success of R\&D Projects: Evidence from American-Israeli Research Alliances,” Research Policy 32 (2003): 1619-1640.

Coase, Ronald H., "The Nature of the Firm," Economica, N.S. 4 (1937): 386-405.

Engardio, Peter, Aaron Bernstein, and Manjeet Kripalani, “Is Your Job Next?” Business Week (February 3, 2003): 50-60. 
Greene, William H., Econometric Analysis, $4^{\text {th }}$ Edition: Prentice-Hall, Upper Saddle River, NJ, 2000.

Grossman, Sanford J., and Oliver Hart, "The Costs and Benefits of Ownership: A Theory of Vertical and Lateral Integration,” Journal of Political Economy 94 (August 1986): 691-719.

Hagedoorn, John, Albert N. Link, and Nicholas S. Vonortas, "Research Partnerships,” Research Policy 29 (2000): 567-586.

Hausman, Jerry, Bronwyn H. Hall, and Zvi Griliches, "Econometric Models for Count Data with an Application to the Patents-R\&D Relationship," Econometrica 52 (July 1984): 909-938.

Holmstrom, Bengt, and John Roberts, “The Boundaries of the Firm Revisited,” Journal of Economic Perspectives 12 (Fall 1998): 73-94.

Kogut, Bruce, "Joint Ventures and the Option to Expand and Acquire," Management Science 37 (January 1991): 19-33. , and Udo Zander, "Knowledge of the Firm, Combinative Capabilities, and the Replication of Technology," Organization Science 3 (August 1992): 383-397.

Jankowski, John E., “Do We Need a Price Index for Industrial R\&D?” Research Policy 22 (1993): 195-205.

Joskow, Paul L., "Contract Duration and Relationship-Specific Investments: Empirical Evidence from Coal Markets,” American Economic Review 77 (March 1987): 168-185.

Leyden, Dennis P., and Albert N. Link, "Federal Laboratories as Research Partners," International Journal of Industrial Organization 17 (1999): 575-592.

Link, Albert N., “Alternative Sources of Technology: An Analysis of Induced Innovation,” Managerial And Decision Economics 4 (March 1983): 40-43. , "Mergers and Acquisitions as a Source of Innovation,” Mergers \& Acquisitions 23 (November/December 1988): 36-39. , and L. Bauer, Cooperative Research in U.S. Manufacturing, Lexington Books, Lexington, Massachusetts: 1989.

Mansfield, Edwin, Mark Schwartz, and Samuel Wagner, "Imitation Costs and Patents: An Empirical Study,” The Economic Journal 91 (December 1981): 907-918. 
Monteverde, Kirk, and David J. Teece, “Supplier Switching Costs and Vertical Integration,” Bell Journal Of Economics 13 (Spring 1982): 206-213.

Mowery, David C., "International Collaborative Ventures and the Commercialization of New

Technologies" in N. Rosenberg, R. Landau, and D. Mowery, editors, Technology and the Wealth Of Nations, Stanford: Stanford University Press, 1992.

, "The Boundaries of the U.S. Firm in R\&D," in N. Lamoreaux and D. Raff, editors, Coordination and Information: Historical Perspectives on the Organization of Enterprise, Chicago: University of Chicago Press for NBER, 1995. , Joanne E. Oxley, and Brian S. Silverman, “Technological Overlap and Inter-Firm Cooperation: Implications for the Resource-Based View of the Firm," Research Policy 27 (1998): 507-523.

National Research Council, Board on Science, technology, and Economic Policy, The Small Business Innovation Research Program: Challenges and Opportunities, Washington, DC, National Academy Press, 1999.

Oxley, Joanne E., “Appropriability Hazards and Governance in Strategic Alliances: A Transaction Cost Approach,” Journal of Law, Economics, and Organization 13 (1997): 387-407.

Pisano, Gary P., "The R\&D Boundaries of the Firm: An Empirical Analysis,” Administrative Science Quarterly 35 (March 1990): 153-176.

Standard and Poor Corporation, Compustat, New York: McGraw-Hill, various years.

Teece, David J., “Technology Transfer by Multi-National Firms: The Resource Cost of Transferring Technological Know-How,” The Economic Journal 87 (June 1977): 242-261.

“The Great Hollowing-Out Myth,” The Economist (February 21, 2004): 27-29.

U.S. Bureau of the Census, 1992 Economic Census CD-ROM 1J, C1-E92-EC1J-07-US1, Washington, DC, 1998.

Von Hippel, Eric, The Sources of Innovation, New York: Oxford University Press, 1988.

Williamson, Oliver, The Economic Institutions of Capitalism, New York: Free Press, 1985. 